\title{
Evolution of nursing teaching in the use of education technology: a scoping review
}

\author{
Evolução do ensino de enfermagem no uso da tecnologia educacional: uma scoping review
}

Evolución de la enseñanza de enfermería en el uso de la tecnología educacional: una revisión sistemática

\section{Mayara Lima Barbosa' \\ ORCID: 0000-0002-8063-7903 \\ Lhana Lorena de Melo Atanasio" \\ ORCID: 0000-0002-1090-1940 \\ Suzane Gomes de Medeiros" ORCID: 0000-0002-4196-4557 \\ Cecília Olívia Paraguai de Oliveira Saraiva" ORCID: 0000-0003-4225-5194 \\ Viviane Euzébia Pereira Santos" ORCID: 0000-0001-8140-8320}

'Centro Universitário Unifacisa. Campina Grande, Paraíba, Brazil.

"Universidade Federal do Rio Grande do Norte. Natal, Rio Grande do Norte, Brazil.

How to cite this article:

Barbosa ML, Atanasio LLM, Medeiros SG, Saraiva COPO, Santos VEP. Evolution of nursing teaching in the use of education technology: a scoping review. Rev Bras Enferm. 2021;74(Suppl 5):e20200422. https://doi.org/10.1590/0034-7167-2020-0422

\section{Corresponding author:}

Mayara Lima Barbosa

E-mail:mayaralimabarbosa@gmail.com

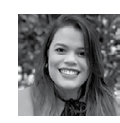

EDITOR CHEFE: Antonio José de Almeida Filho ASSOCIATE EDITOR: Rafael Silva

Submissão: 09-07-2020

Approval: 01-09-2021

\section{ABSTRACT}

Objective: To identify and map the technological tools of information and communication to support the teaching learning process in Nursing teaching courses. Methods: This is a scoping review whose search was carried out in seven databases and in grey literature. After an initial analysis of the selection, 88 texts were read integrally, and 29 made up the final sample. Results: Virtual learning environment and object, simulation, hypermedia, and software or cellphone applications were the tools the nursing professors used the most. Studies highlight that the application of technology was important in the teaching-learning process, since it encouraged teaching based on safe care, motivating and developing abilities/competences, supported on significant, effective, flexible, and autonomous learning Conclusion: The contribution of the technology for nursing formation stands out, but it should be highlighted that its employment must be critical, reflective, based on pedagogical theories and developed by trained professors.

Descriptors: Information Technology. Educational Technology. Education, Nursing. Nursing. Teaching.

\section{RESUMO}

Objetivo: Identificar e mapear as ferramentas tecnológicas da informação e comunicação para apoio ao processo de ensino-aprendizagem em cursos de graduação em Enfermagem. Métodos: Trata-se de uma scoping review, cuja busca foi realizada em sete bases de dados e na literatura cinzenta. Após a análise da seleção inicial, 88 textos foram lidos na íntegra e 29 compuseram a amostra final. Resultados: $O$ ambiente e objeto virtual de aprendizagem, simulação, hipermídia e software ou aplicativos para celular foram as ferramentas utilizadas pelos docentes de Enfermagem. Os estudos destacam que a aplicação da tecnologia foi importante no processo de ensino-aprendizagem, pois estimulou o ensino baseado no cuidado seguro, motivou e desenvolveu habilidades/competências, apoiando-se na aprendizagem significativa, efetiva, flexível e autônoma. Conclusão: Destaca-se a contribuição da tecnologia para a formação de enfermagem, mas é salutar ressaltar que seu emprego seja crítico, reflexivo, embasado em teorias pedagógicas e desenvolvido por docentes capacitados. Descritores: Tecnologia Educacional; Tecnologia da Informação; Educação em Enfermagem; Ensino; Enfermagem.

\section{RESUMEN}

Objetivo: Identificar y mapear herramientas tecnológicas de la información y comunicación para apoyo al proceso de enseñanza-aprendizaje en cursos de grado en Enfermería. Métodos: Tratase de una scoping review, cuya búsqueda realizada en siete bases de datos y en la literatura gris. Después del análisis de selección inicial, 88 textos fueron leídos integralmente y 29 compusieron la muestra final. Resultados: El ambiente y objeto virtual de aprendizaje, simulación, hipermedia y software o aplicativos para celular fueron las herramientas utilizadas por los docentes de Enfermería. Estudios destacan que aplicación de la tecnología fue importante en el proceso de enseñanza-aprendizaje, pues estimuló la enseñanza basada en el cuidado seguro, motivó y desarrolló habilidades/competencias, apoyándose en el aprendizaje significativo, efectivo, flexible y autónomo. Conclusión: Destacase contribución de la tecnología para la formación de enfermería, pero es bueno destacar que su empleo sea crítico, reflexivo, basado en teorías pedagógicas y desarrollado por docentes capacitados. Descriptores: Tecnología Educacional; Tecnología de la Información; Educación en Enfermería; Enseñanza; Enfermería. 


\section{INTRODUCTION}

The advance of information and communications technology (ICT) - understood as an instrument capable of aggregating, connecting, operating, and disseminating information ${ }^{(1)}$ - which took place in the last decades, starting with the popularization of the world wide web (web) has promoted a process according to which personal relations become virtual, related to their growing use in daily life ${ }^{(2)}$.

This technological evolution, in turn, managed to affect nursing education, which has been inserting ICT in its teaching-learning processes. It is seen as an effective support strategy, capable of optimizing teaching practices as it guarantees that the professor can perform the essential mission of facilitating the learning pro$\operatorname{cess}^{(2)}$. When unique and modern activities are added to traditional classes, the use of ICTs favors a dynamic process of learning ${ }^{(3)}$.

Its employment diminishes the distance between students and professors, facilitating access and making it more flexible to many people, encouraging autonomy and reflection about their learning, since it involves the student in an articulated process of strategies and resources related to the use of technology ${ }^{(4)}$. Still, it can be implemented in emergency situations, in which in-person teaching cannot take place, due to risks to the safety of students and professors, such as the COVID-19 pandemic.

The insertion of ICTs in the Political-Pedagogical Projects (PPP) is a reality prescribed by Decree No. 2.117/2019, according to which higher teaching institutions can include in their PPP teaching-learning methods and practices that incorporate the use of ICTs as supplementary tools. Up to $40 \%$ of the total workload of in-person courses, including nursing, can be carried out as distance education (DE) ${ }^{(5)}$.

It is important to highlight that the Decree also clarifies that the PPP must present clearly and objectively how will the incorporation of the ICTs be done to reach pedagogical objectives. As a result, one must advocate the introduction of technology in the educational process to happen in a critical, reflexive way, articulated with teaching and adapted to the social, political, and economic context of the students ${ }^{(6)}$.

To do so, there must be an analysis of the aspects of the teaching/learning process related to the form in which students learn and assimilate, the social, historic, and cultural determinants, so educational formation is not impaired, and, therefore, qualified professionals are formed ${ }^{(7)}$.

For nursing, the insertion of ICTs allows for new forms of learning, based on interaction, student autonomy, and new experiences. It can be understood that this technology does not aim at replacing traditional teaching models, but to give support to this process as an educational resource or reorient and/or update the workers and their service ${ }^{(8)}$. The insertion of technologies in the teaching learning process is based on the cyberculture theory, which states that knowledge is something dynamic, and interacts with research centers, databases, media storage, and recording devices, through digital and mobile networks ${ }^{(7)}$.

Considering the above, this study considers the modernization and evolution of the forms of teaching in the field of nursing, including the use of ICTs, to increase the access to information by nursing students, since it would enable the improvement of teaching-learning ${ }^{(9)}$. It aims to identify and map the technological tools of information and communication for the support the teaching-learning process in nursing teaching courses.

\section{METHODS}

This is a scoping review in accordance to the recommendations of the JBI Institute Reviewer's Manual ${ }^{(10)}$. The stages carried out were: identification of the research question; identification of relevant studies; study selection; data analysis and collection; abstract; and construction of the report. The research protocol was registered in the Open Science Framework (https://osf.io/6xb2j/) and followed the PRISMA checklist for this type of study ${ }^{(11)}$. The population of the investigation was built by researches related to the technological tools of information and communication used by professors for the learning teaching process in nursing graduation courses.

The research question formulated followed the precepts established by the PCC strategy: population, concept, and context, elements which, in this study, corresponded, respectively, to nursing professors; information and communications technologies; and nursing graduation courses. Therefore, the guiding question was: What are the information and communications technology tools used by the professors for the teaching learning process in Nursing graduation courses?

Data search took place from March to April 2020. For data collection, the MESH descriptors related to the PCC were identified: P - Health Educator; C -Educational Technology; and C - Education, Nursing, Graduate. Based on that, an initial consultation was carried out in the PubMed portal and in the database CINAHL, for the identification of descriptors and keywords that are frequently used in the studies that addressed the theme of interest. The resulting research strategy is described in Chart 1.

Chart 1 - Scoping review search strategy, Brazil, 2020

HEALTH EDUCATOR OR nursing OR nurses AND EDUCATIONAL

TECHNOLOGY OR electronic health information OR mobile Technologies

OR self-regulated learning OR Web-based simulation OR consumer

health information $O R$ distance education OR eHealth OR e-Learning $O R$

learning, framework OR Mobile learning OR mobile technology OR Multilevel OR learners OR New Technologies OR nursing informatics OR online learning $O R$ On-line learning $O R$ self-directed learning $O R$ simulation $O R$ smartphone $O R$ students-patient simulation $O R$ teaching strategies $O R$ technology OR technology-enabled learning OR virtual worlds OR Web Quest OR Webinars AND EDUCATION, NURSING, GRADUATE OR education $O R$ Nursing education $O R$ graduate education $O R$ nursing education $O R$ health care education.

For this stage, the following databases were used:U.S. National Library of Medicine (PubMed), Cumulative Index to Nursing and Allied Health Literature (CINAHL), Web of Science, Scopus, Literatura Latino-Americana e do Caribe em Ciências da Saúde (LILACS), Cochrane CENTRAL, PsychINFO, and the Education Resources Information Center (ERIC). From gray literature, the following were used: the Portal of Thesis and Dissertations form the Coordenação de Aperfeiçoamento de Pessoal de Nível Superior (the Coordination for the Improvement of Higher Education Personal - Brazil), The National Library of Australia's Trobe (Australia and New Zeland), Academic Archive Online (Sweden and other Scandinavian countries), DART-Europe E-Theses Portal (Europe), 
Electronic Theses Online Service (United Kingdom), Repositório Científico de Acesso Aberto de Portugal (Portugal's Open-Access Science Repository - Portugal), National Electronic Theses and Dissertations Portal (South Africa), and Theses Canada (Canada).

The study included researches published in-full, whose subject was the use of information and communications technology tools employed for the teaching-learning nursing process. In order to capture the original use of technologies in the teaching of nursing, the following types of texts were excluded: editorials, experience reports, theoretical essays, reflection studies, revisions, and researches without an abstract or an on-line text published in-full. However, data collection was carried out in the platform Comunidade Acadêmica Federada (Federated Academic Community), in order to cut down losses. It is important to highlight that no time limit was selected.

For the initial selection and evaluation of the studies, all bibliographic references resulting from databases were allocated in a generator of bibliographic references: EndNote Web. The early selection found 28,923 texts and, after the process of study exclusion, the final sample was made up by 29 documents. It is pertinent to highlight that two trained reviewers were paired to carry out these stages independently, and a third reviewer was responsible for evaluating divergences.

The data extracted, allocated in a Microsoft Excel sheet, includes: title; country of origin and year of publication; design and number of participants; methodological design; results and conclusions of the research; and the tool used for the process of nursing teaching-learning.

\section{RESULTS}

The initial selection found 28,923 texts. After duplicates were excluded, the total was 28,915 works. Later, the titles and abstracts of all studies were identified, considering the inclusion and exclusion criteria established, leading to the exclusion of 28,827 publications. Later, the 88 documents left were read infull, and those that did not answer to the guiding question were excluded, making up a final sample of 29 researches (Figure 1).

Chart 2 presents the characterization of publications according to title; country of origin and year of publications of studies included in the scoping review; design and number of participants; interventions and outcomes, considering each type of research included in the review. Regarding the country of origin of the studies, 19 are from Brazil, 3 from South Korea, and 2 from Iran. The other countries (Canada, United States, Australia, Portugal, and Spain) had one study each included. Regarding the year of publication, there were five studies in 2015; four in 2012; three in 2009, 2011, 2013, 2016, and 2016; two in 2017 and in 2019; and only one study in 2014.

With regard to ICT tools (Table 1) used in the studies included, it can be noted that a large part of the studies (45\%) used the virtual learning environment (especially Moodle) to teach in nursing graduation courses. The technologies used the least were web platforms and videos, with two papers $(6.9 \%)$ each.

The main results and conclusions (Table 2 ) showed that the application of ICTs was a tool to increase the motivation and satisfaction of students (20\%) and an effective learning process (20\%).

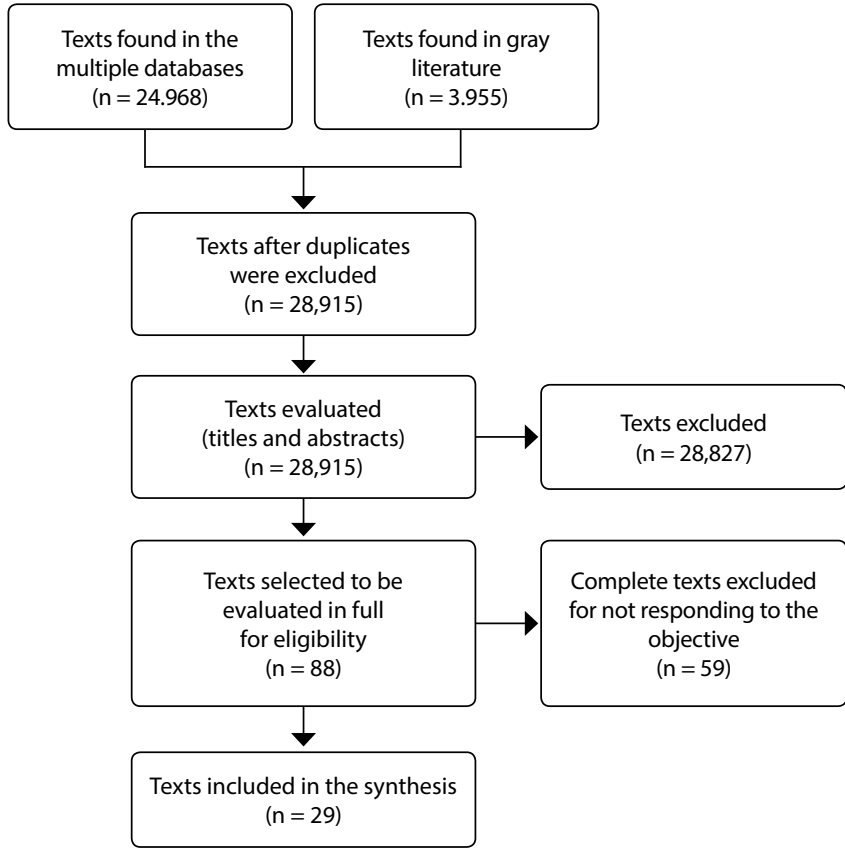

Figure 1 - Flowchart for the selection of the studies included in the scoping review, Brazil, 2020

Chart 2 - Characterization according to title, country of origin and year of publication, design and number of participants interventions and outcomes of the studies from the scoping review $(n=29)$, Brazil, 2020

\begin{tabular}{|c|c|c|c|c|}
\hline ID & Title & $\left|\begin{array}{c}\text { Yearl } \\
\text { Country }\end{array}\right|$ & $\begin{array}{l}\text { Design/ } \\
\text { number of } \\
\text { participants }\end{array}$ & $\begin{array}{l}\text { Methodological } \\
\text { design }\end{array}$ \\
\hline T1 & $\begin{array}{l}\text { An educational } \\
\text { proposal to teach } \\
\text { apressure ulcer } \\
\text { management } \\
\text { course online } \\
\text { to students } \\
\text { and nursing } \\
\text { professionals }\end{array}$ & $\begin{array}{l}2009 \\
\text { Brazil }\end{array}$ & $\begin{array}{l}\text { Applied } \\
\text { research/ } \\
\text { Does not apply }\end{array}$ & Does not apply \\
\hline $\mathrm{T} 2$ & $\begin{array}{l}\text { Web-based } \\
\text { simulation: a tool } \\
\text { for teaching critical } \\
\text { care nursing. Rev. } \\
\text { latinoam. enferm }\end{array}$ & $\begin{array}{l}2009 \\
\text { Brazil }\end{array}$ & $\begin{array}{l}\text { Applied } \\
\text { research/ } \\
\text { Does not apply }\end{array}$ & Does not apply \\
\hline T3 & $\begin{array}{l}\text { Evaluation of a } \\
\text { Complementary } \\
\text { CyberEducation } \\
\text { Program for a } \\
\text { Pathophysiology } \\
\text { Class }^{(14)}\end{array}$ & $\begin{array}{l}2009 \\
\text { South } \\
\text { Korea }\end{array}$ & $\begin{array}{l}\text { Intervention } \\
\text { study } \\
n=121\end{array}$ & $\begin{array}{l}\text { Use of technology } \\
\text { in teaching versus } \\
\text { traditional teaching }\end{array}$ \\
\hline T4 & $\begin{array}{l}\text { Virtual objects } \\
\text { to support the } \\
\text { teaching-learning } \\
\text { process of physical } \\
\text { examination in } \\
\text { nursing }\end{array}$ & $\begin{array}{l}2011 \\
\text { Brazil }\end{array}$ & $\begin{array}{l}\text { Methodological } \\
\text { study } \\
\text { / Does not } \\
\text { apply }\end{array}$ & Does not apply \\
\hline T5 & $\begin{array}{l}\text { Learning Outcomes } \\
\text { in Two Different } \\
\text { Teaching Approach } \\
\text { in Nursing } \\
\text { Education in Iran: } \\
\text { E-Learning versus } \\
\text { Lecture }^{(16)}\end{array}$ & $\begin{array}{l}2011 \\
\text { Iran }\end{array}$ & $\begin{array}{l}\text { Cross-over } \\
\text { intervention } \\
\text { study } \\
n=32\end{array}$ & $\begin{array}{l}\text { Use of e-learning } \\
\text { versus traditional } \\
\text { teaching }\end{array}$ \\
\hline
\end{tabular}

To be continued 
Chart 1

\begin{tabular}{|c|c|c|c|c|}
\hline ID & Title & $\mid \begin{array}{c}\text { Year/ } \\
\text { Country }\end{array}$ & $\begin{array}{l}\text { Design/ } \\
\text { number of } \\
\text { participants }\end{array}$ & $\begin{array}{l}\text { Methodological } \\
\text { design }\end{array}$ \\
\hline T6 & $\begin{array}{l}\text { Virtual education } \\
\text { effect on cognitive } \\
\text { learning and } \\
\text { attitude of nursing } \\
\text { students towards } \\
\text { it }^{(17)}\end{array}$ & $\begin{array}{l}2011 \\
\text { Iran }\end{array}$ & $\begin{array}{l}\text { Quasi- } \\
\text { experimental } \\
\text { pre-test and } \\
\text { post-test } \\
n=33\end{array}$ & $\begin{array}{l}\text { Virtual education } \\
\text { versus conventional } \\
\text { education }\end{array}$ \\
\hline $\mathrm{T} 7$ & $\begin{array}{l}\text { Teaching the } \\
\text { nursing process to } \\
\text { undergraduates } \\
\text { with the support } \\
\text { of computer } \\
\text { technology }{ }^{(18)}\end{array}$ & $\begin{array}{l}2012 \\
\text { Brazil }\end{array}$ & $\begin{array}{l}\text { Cross-sectional } \\
\text { study } \\
\text { / Does not } \\
\text { apply }\end{array}$ & Does not apply \\
\hline T8 & $\begin{array}{l}\text { Construction } \\
\text { and validation of } \\
\text { an educational } \\
\text { hypermedia } \\
\text { about peripheral } \\
\text { catheterization }^{(19)}\end{array}$ & $\begin{array}{l}2012 \\
\text { Brazil }\end{array}$ & $\begin{array}{l}\text { Methodological } \\
\text { research and } \\
\text { pre-test and } \\
\text { post-test } \\
\text { evaluation } \\
\mathrm{n}=21\end{array}$ & Use of technology \\
\hline T9 & $\begin{array}{l}\text { Mental Health } \\
\text { care: a system } \\
\text { for teaching in } \\
\text { Nursing }^{(20)}\end{array}$ & $\begin{array}{l}2012 \\
\text { Brazil }\end{array}$ & $\begin{array}{l}\text { Applied } \\
\text { research/ } \\
\text { / Does not } \\
\text { apply }\end{array}$ & Does not apply \\
\hline T10 & $\begin{array}{l}\text { Multimedia } \\
\text { application in } \\
\text { mobile platform } \\
\text { for teaching the } \\
\text { measurement of } \\
\text { central venous } \\
\text { pressure }^{(21)}\end{array}$ & $\begin{array}{l}2012 \\
\text { Brazil }\end{array}$ & $\begin{array}{l}\text { Applied } \\
\text { research/ } \\
\text { / Does not } \\
\text { apply }\end{array}$ & Does not apply \\
\hline T11 & $\begin{array}{l}\text { Using Moodle } \\
\text { in the Discipline } \\
\text { of Nursing } \\
\text { Informatics }\end{array}$ & $\begin{array}{l}2013 \\
\text { Brazil }\end{array}$ & $\begin{array}{l}\text { Cross-sectional } \\
\text { study } \\
n=82\end{array}$ & Does not apply \\
\hline $\mathrm{T} 12$ & $\begin{array}{l}\text { The Impact of } \\
\text { Blended Teaching } \\
\text { on Knowledge, } \\
\text { Satisfaction, and } \\
\text { Self-Directed } \\
\text { Learning in Nursing } \\
\text { Undergraduates: } \\
\text { A Randomized, } \\
\text { Controlled Trial(23) }\end{array}$ & $\begin{array}{c}2013 \\
\text { Canada }\end{array}$ & $\begin{array}{l}\text { Intervention } \\
\text { study } \\
\mathrm{n}=112\end{array}$ & $\begin{array}{l}\text { Use of mixed } \\
\text { teaching versus } \\
\text { traditional teaching }\end{array}$ \\
\hline T13 & $\begin{array}{l}\text { Millennial } \\
\text { Generation } \\
\text { Student Nurses' } \\
\text { Perceptions of the } \\
\text { Impact of Multiple } \\
\text { Technologies on } \\
\text { Learning }^{(24)}\end{array}$ & $\begin{array}{l}2013 \\
\text { USA }\end{array}$ & $\begin{array}{l}\text { Cross-sectional } \\
\text { study } \\
n=60\end{array}$ & Does not apply \\
\hline $\mathrm{T} 14$ & $\begin{array}{l}\text { Development } \\
\text { and assessment } \\
\text { of learning } \\
\text { objects about } \\
\text { intramuscular } \\
\text { medication } \\
\text { administration }^{(25)}\end{array}$ & $\begin{array}{l}2014 \\
\text { Brazil }\end{array}$ & $\begin{array}{l}\text { Applied } \\
\text { research/ } \\
\text { / Does not } \\
\text { apply }\end{array}$ & Does not apply \\
\hline T15 & $\begin{array}{l}\text { Digital learning } \\
\text { object for } \\
\text { diagnostic } \\
\text { reasoning in } \\
\text { nursing applied to } \\
\text { the integumentary } \\
\text { system }^{(26)}\end{array}$ & $\begin{array}{l}2015 \\
\text { Brazil }\end{array}$ & $\begin{array}{l}\text { Methodological } \\
\text { study } \\
\text { / Does not } \\
\text { apply }\end{array}$ & Does not apply \\
\hline
\end{tabular}

To be continued
Chart

\begin{tabular}{|c|c|c|c|c|}
\hline ID & Title & $\begin{array}{c}\text { Year/ } \\
\text { Country }\end{array}$ & $\begin{array}{l}\text { Design/ } \\
\text { number of } \\
\text { participants }\end{array}$ & $\begin{array}{l}\text { Methodological } \\
\text { design }\end{array}$ \\
\hline T16 & $\begin{array}{l}\text { Instructional } \\
\text { design to develop } \\
\text { an online course } \\
\text { on urinary } \\
\text { catheterization }^{(27)}\end{array}$ & $\begin{array}{l}2015 \\
\text { Brazil }\end{array}$ & $\begin{array}{l}\text { Methodological } \\
\text { study } \\
\text { / Does not } \\
\text { apply }\end{array}$ & Does not apply \\
\hline T17 & $\begin{array}{l}\text { Teaching and } \\
\text { Learning in a Virtual } \\
\text { Environment: } \\
\text { Nursing Students' }^{\text {Attitude }}{ }^{(28)}\end{array}$ & $\begin{array}{l}2015 \\
\text { Brazil }\end{array}$ & $\begin{array}{l}\text { Before-and- } \\
\text { after quasi- } \\
\text { experimental } \\
\text { study } \\
n=28\end{array}$ & Use of technology \\
\hline T18 & $\begin{array}{l}\text { Effects of web-based } \\
\text { electrocardiography } \\
\text { simulation on } \\
\text { strategies and } \\
\text { learning styles }^{(29)}\end{array}$ & $\begin{array}{l}2015 \\
\text { Brazil }\end{array}$ & $\begin{array}{l}\text { Descriptive- } \\
\text { correlational } \\
\text { study with } \\
\text { pre-test and } \\
\text { post-test } \\
\text { evaluations } \\
n=246\end{array}$ & $\begin{array}{l}\text { Electrocardiographic } \\
\text { Internet simulation }\end{array}$ \\
\hline T19 & $\begin{array}{l}\text { Lights, camera } \\
\text { and action in the } \\
\text { implementation } \\
\text { of central venous } \\
\text { catheter dressing }^{(30)}\end{array}$ & $\begin{array}{l}2015 \\
\text { Brazil }\end{array}$ & $\begin{array}{l}\text { Methodological } \\
\text { study } \\
\text { / Does not } \\
\text { apply }\end{array}$ & Does not apply \\
\hline T20 & $\begin{array}{l}\text { Development of } \\
\text { a course in the } \\
\text { Virtual Learning } \\
\text { Environment on the } \\
\text { ICNP } \\
\text { (31) }\end{array}$ & $\begin{array}{l}2016 \\
\text { Brazil }\end{array}$ & $\begin{array}{l}\text { Descriptive and } \\
\text { cross-sectional } \\
\text { study } \\
\text { / Does not } \\
\text { apply }\end{array}$ & Does not apply \\
\hline T21 & $\begin{array}{l}\text { Use and } \\
\text { development } \\
\text { of teaching } \\
\text { technologies } \\
\text { presented in } \\
\text { nursing research }\end{array}$ & $\begin{array}{l}2016 \\
\text { Brazil }\end{array}$ & $\begin{array}{l}\text { Document } \\
\text { research } \\
\text { / Does not } \\
\text { apply }\end{array}$ & Does not apply \\
\hline T22 & $\begin{array}{l}\text { Mobile-Based Video } \\
\text { Learning Outcomes } \\
\text { in Clinical Nursing } \\
\text { Skill Education }^{(33)}\end{array}$ & $\begin{array}{l}2016 \\
\text { South } \\
\text { Korea }\end{array}$ & $\begin{array}{l}\text { Controlled } \\
\text { randomized } \\
\text { trial with pre- } \\
\text { and post-tests } \\
\mathrm{n}=74\end{array}$ & $\begin{array}{l}\text { Use of educational } \\
\text { technologies }\end{array}$ \\
\hline T23 & $\begin{array}{l}\text { Teaching-learning } \\
\text { evaluation on the } \\
\text { ICNP }^{\circledR} \text { using virtual } \\
\text { learning } \\
\text { environment }^{(34)}\end{array}$ & $\begin{array}{l}2017 \\
\text { Brazil }\end{array}$ & $\begin{array}{l}\text { Mixed research } \\
n=51\end{array}$ & Does not apply \\
\hline T24 & $\begin{array}{l}\text { The effects of an } \\
\text { online basic life } \\
\text { support course on } \\
\text { undergraduate } \\
\text { nursing students' } \\
\text { learning }^{(35)}\end{array}$ & $\begin{array}{l}2017 \\
\text { Brazil }\end{array}$ & $\begin{array}{l}\text { Quasi- } \\
\text { experimental } \\
\text { study } \\
n=94\end{array}$ & $\begin{array}{l}\text { Use of educational } \\
\text { technologies }\end{array}$ \\
\hline T25 & $\begin{array}{l}\text { The use of } \\
\text { gamification to } \\
\text { teach in the nursing } \\
\text { field }^{(4)}\end{array}$ & $\begin{array}{l}2018 \\
\text { Brazil }\end{array}$ & $\begin{array}{l}\text { Exploratory } \\
\text { research, } \\
\text { applied } \\
\mathrm{n}=15\end{array}$ & Does not apply \\
\hline T26 & $\begin{array}{l}\text { The Effects of an } \\
\text { Interactive Nursing } \\
\text { Skills Mobile } \\
\text { Application on } \\
\text { Nursing Students' } \\
\text { Knowledge, } \\
\text { Self-efficacy, and } \\
\text { Skills Performance: } \\
\text { A Randomized } \\
\text { Controlled Trial }{ }^{(36)}\end{array}$ & $\begin{array}{l}2018 \\
\text { South } \\
\text { Korea }\end{array}$ & $\begin{array}{l}\text { Experimental } \\
\text { research } \\
n=66\end{array}$ & $\begin{array}{l}\text { Use of technology } \\
\text { versus traditional } \\
\text { teaching }\end{array}$ \\
\hline
\end{tabular}


Chart 1 (concluded)

\begin{tabular}{|c|c|c|c|c|}
\hline ID & Title & $\begin{array}{c}\text { Year/ } \\
\text { Country }\end{array}$ & $\begin{array}{l}\text { Design/ } \\
\text { number of } \\
\text { participants }\end{array}$ & $\begin{array}{l}\text { Methodological } \\
\text { design }\end{array}$ \\
\hline T27 & $\begin{array}{l}\text { Developing nursing } \\
\text { and midwifery } \\
\text { students' capacity } \\
\text { for coping with } \\
\text { bullying and } \\
\text { aggression in } \\
\text { clinical settings: } \\
\text { Students' } \\
\text { evaluation of a } \\
\text { learning resource }\end{array}$ & $\begin{array}{c}2018 \\
\text { Australia }\end{array}$ & $\begin{array}{l}\text { Intervention } \\
\text { study } \\
n=210\end{array}$ & $\begin{array}{l}\text { Use of mixed } \\
\text { teaching methods }\end{array}$ \\
\hline T28 & $\begin{array}{l}\text { Clinical Virtual } \\
\text { Simulation in } \\
\text { Nursing Education: } \\
\text { Randomized } \\
\text { Controlled Trial(38) }^{(38}\end{array}$ & $\begin{array}{c}2019 \\
\text { Portugal }\end{array}$ & $\begin{array}{l}\text { Randomized } \\
\text { clinical trial } \\
n=42\end{array}$ & $\begin{array}{l}\text { Use of technology } \\
\text { versus traditional } \\
\text { teaching }\end{array}$ \\
\hline T29 & $\begin{array}{l}\text { Impact of } \\
\text { educational games } \\
\text { on academic } \\
\text { outcomes of } \\
\text { students in the } \\
\text { Degree in Nursing }\end{array}$ & $\begin{array}{l}2019 \\
\text { Spain }\end{array}$ & $\begin{array}{l}\text { Prospective } \\
\text { quasi- } \\
\text { experimental } \\
\text { study } \\
n=116\end{array}$ & Use of technology \\
\hline
\end{tabular}

Table 1 - Technology of information and communications tools used in the studies $(n=29)$, Brazil, 2020

\begin{tabular}{lcc}
\hline Technology of information and communications & \multicolumn{2}{c}{ Total } \\
tools used & n & \% \\
\hline Virtual learning environment & 13 & 45.0 \\
Simulation & 3 & 10.3 \\
Virtual learning object & 3 & 10.3 \\
Hypermedia & 3 & 10.3 \\
Software or telephone applications & 3 & 10.3 \\
Web platform & 2 & 6.9 \\
Videos & 2 & 6.9 \\
\hline
\end{tabular}

Table 2 - Main results and conclusions for the application of information and communications technology according to the studies included in the scoping review, Brazil, 2020

\begin{tabular}{lcc}
\hline Results and conclusions & $\mathbf{n}^{*}$ & $\%$ \\
\hline Tools to promote motivation and satisfaction with learning & 9 & 20.0 \\
Tools for an effective learning & 9 & 20.0 \\
Complementary tools for the learning process & 8 & 17.8 \\
Tools to develop abilities and competences & 8 & 17.8 \\
Tools for flexible and autonomous learning & 7 & 15.5 \\
Teaching tools that generate safe care & 4 & 8.9 \\
\hline Note: ${ }^{*} n=45$, since there are researches in this review which have more than one result.
\end{tabular}

\section{DISCUSSION}

The evolution of nursing and its formation are consonant with the technological revolution that permeates current relations. Therefore, the use of ICTs in nursing teaching has been offering results in this process, since the integration and organization of the content of disciplines guarantees support to the professors during this stage, in addition to encouraging the autonomy of students with regard to their own learning ${ }^{(39)}$.

The efficient employment of ICTs takes place throughout the world: its usefulness was shown to be viable for educational practices, and its use has been growing in contemporary society ${ }^{(2)}$. The explanation for this phenomenon may be related to new generations of students, who were born and grew surrounded by technologies, in a process of digital inclusion which has allowed for the adaptation to the use of ICTs rapidly and naturally ${ }^{(40)}$.

Furthermore, these young nursing students are creative, and, during their higher education, they seek to develop new abilities and competences, in an active and participative way. This setting contributes for the evolution of pedagogical practices which are currently based on horizontal relations of exchange of knowledge ${ }^{(40)}$.

This reality is also motivated by the availability of Web 3.0. In the past, Internet navigation was static, with no images and an uninteresting graphic interface (the so-called Web 1.0). Later, with Web 2.0, advances made it possible to interact with websites and to create web pages in which texts, images, music, or videos could be published. Now, with the advent of Web 3.0, its interfaces can even be programmed, which makes it easier to communicate and increases the use if $\mathrm{ICT}^{(4)}$.

Considering the growth of ICT applications in a setting which highlights the benefits of its use, the increase in the number of scientific publications in the last few years is perceivable ${ }^{(41)}$, as are the multiple tools implemented for the teaching of nursing in higher education $^{(42)}$. At first, learning through technologies was carried out through telephone or television courses; later, the Internet became more popular, increasing the interaction between people, and virtual learning environments gained space with distance education, as a way to complement in-person education ${ }^{(1)}$.

Currently, ICTs can be employed in many ways, among which virtual clinic simulations, virtual learning objects, hypermedia, web platforms, videos, and cellphone applications, according to the texts included in this revision. In general, these tools are characterized by their interactivity, multimedia support, hypermediatic language, and reusability, being a strong support for learning in many levels of formation ${ }^{(43)}$, since it is consolidated teaching, which contributes for patient safety ${ }^{(44)}$.

It stands out that the use of ICTs must not be a strategy to simply and uncritically make available the content for nursing formation; pedagogical theories must be applied in a critical and reflective process, so the benefits that arise from its application can be perceived and optimized ${ }^{(1)}$.

There are many results from the application of ICTs in nursing graduation courses. According to texts T2, T3, T5, T6, T7, T8, T11, and $T 25$, it can be noted that their use was shown to be beneficial for the learning of nursing students as a complementary tool. In this case, ICTs are not only related to distance education, being also used during in-person classes to good results ${ }^{(39)}$ : they are innovative methods and tools that aid in the exemplification of fictional or real setting $s^{(1)}$, as opposed to traditional and static teaching methods ${ }^{(3)}$.

That said, the union between the traditional and the modern has increased student motivation for learning, according to texts $\mathrm{T} 3, \mathrm{~T} 5, \mathrm{~T} 12, \mathrm{~T} 14, \mathrm{~T} 18, \mathrm{~T} 22, \mathrm{~T} 25, \mathrm{~T} 28$, and T29. The elaboration of friendly, motivational, and interactive tools ${ }^{(31)}$ has contributed for these results, and also foment the development of many competences $^{(43)}$.

Texts $\mathrm{T} 2, \mathrm{~T} 10, \mathrm{~T} 12, \mathrm{~T} 14, \mathrm{~T} 16, \mathrm{~T} 18$, and $\mathrm{T} 22$ highlight ICTs as tools for a flexible and autonomous learning. This result is motivated by the capacity this strategy presents with regard to the availability of content and to the independent interaction between 
technology and student, which makes students responsible for their learning ${ }^{(39)}$.

Still, factors such as the freedom of the student to choose and define their study hours and rhythm, as long as they do it critically, facilitate learning, favoring the process of reflection and the use of previous experiences - according to the new National Curricular Guidelines ${ }^{(45)}$ — and bring forth a feeling of empowerment ${ }^{(9)}$.

This encouragement to develop abilities and competences was highlighted in studies T11, T4, T22, T24, T25, T26, T27, and T29 (many of which produced in Brazil), consonant with the National Curricular Guidelines for graduation courses in the field of health. This legislation highlights that the process of formation of the professionals must undergo changes aimed at encouraging abilities and competences for professional practice, encouraging critical thought and the assimilation of new content in distinct ways ${ }^{(46)}$.

Therefore, its use could represent an adequate way to guarantee the access to information that can qualify the practices of future health professionals with regard to the needs of the collective ${ }^{(9)}$, exploring the potential of interactivity and collaboration ${ }^{(47)}$ and favoring an in-depth look at the content, in articulation with professional practice ${ }^{(48)}$.

The studies T9, T11, T14, and T15 highlighted, in their final considerations, the importance of applying ICTs for safe care during formation, since, based on the usability of technologies, students can, a priori, simulate real situations and train abilities, for later application of their knowledge in real patients. This allows them to develop their activities with more safety, that is, offers them the opportunity to learn and/or train, repeatedly, and allows nursing students to feel self-confident when facing concrete situations $^{(49)}$.

According to texts $\mathrm{T} 1, \mathrm{~T} 2, \mathrm{~T} 3, \mathrm{~T} 4, \mathrm{~T} 6, \mathrm{~T} 10, \mathrm{~T} 11, \mathrm{~T} 17$, and $\mathrm{T} 18$, the use of ICTs for teaching nursing students made the generation of effective knowledge viable. Literature shows that studies about ICT application demonstrate that it does lead to the acquisition of knowledge. This reality is associated to the way in which learning is developed based on ICTs, in which experience is individual, significant, and reflective, and whose process is particularly encouraging to students, and the result is the changing of previous conceptions ${ }^{(49)}$.

\section{Study limitations}

The limitation of this study is the exclusion of some types of study designs.

\section{Contributions to the Field of Nursing}

Considering the encouragement of the use of ICTs in nursing teaching, this study informs general aspects of the tools used, and shows the main results and conclusions relative to the application of technologies, as articulated with current literature and legislation. With this regard, it encourages discussions about the theme, contributing to qualify the use of information and communications technologies to teach nursing graduation courses.

\section{CONCLUSIONS}

The evolution in nursing education is a reality that goes hand in hand with the modernization of teaching, in which the use of ICTs is growing, as the results of this revision show. Its use is likely to be even greater in the country, due to the legislation that allows the institution of distance education disciplines.

Among the results of this study, the use of ICTs as tools for the professor to complement in-person teaching can be noted, as does its use related to effective, flexible and autonomous teaching, capable of promoting safe care, abilities, competences, and the motivation of students. Among its most used tools, the virtual learning environments stand out, as do the simulations, the virtual learning objects, hypermedia, web platforms, videos, and cellphone applications.

Finally, it stands out that the implementation of ICTs targeted at learning must be in line with pedagogical theories, in order to guarantee a critical and reflective application by professors and students. Still, it should be said that it is paramount to train the professors, to develop their abilities and competences in the use of these technologies.

\section{FUNDING}

Capes.

\section{REFERENCES}

1. Torres AAL, Bezerra JAA, Abbad GS. Uso de tecnologias de informação e comunicação no ensino na saúde: revisão sistemática 2010-2015. Rev Gestão Saúde [Internet]. 2015 [cited 2020 Apr 12];6(2):1883-89. Available from: https://periodicos.unb.br/index.php/rgs/article/view/3030/2726

2. Castro MJ, López M, Cao MJ, Fernández-Castro M, García S, Frutos M, et al. Impact of educational games on academic outcomes of students in the Degree in Nursing. PLoS One. 2019;14(7):e0220388. https://doi.org/10.1371/journal.pone.0220388

3. Gediel ALB, Soares CP, Oliveira CLR. O ambiente virtual como aliado no processo de ensino e aprendizagem da Libras. Rev (Con)Tex Ling[Internet]. 2016 [cited 2020 Apr 10];10(16):24-37. Available from: https://periodicos.ufes.br/contextoslinguisticos/article/view/13701

4. Castro TC, Gonçalves LS. The use of gamification to teach in the nursing field. Rev Bras Enferm. 2018;71(3):1038-45. https://doi. org/10.1590/0034-7167-2017-0023 Portuguese.

5. Ministério da Educação (BR). Portaria n. 2.117, de 6 de dezembro de 2019. Dispõe sobre a oferta de carga horária na modalidade de Ensino a Distância - EaD em cursos de graduação presenciais ofertados por Instituições de Educação Superior - IES pertencentes ao Sistema Federal de Ensino [Internet]. 2019[cited 2020 Apr 14]. Available from: http://www.in.gov.br/en/web/dou/-/ portaria-n-2.117-de-6-de-dezembro-de-2019-232670913 
6. Bussotti EA, Leite MTM, Alves ACC, Cristensen K. Online training for health professionals in three regions of Brazil. Rev Bras Enferm. 2016;69(5):981-5. https://doi.org/10.1590/0034-7167.2016690506

7. Lévy P. A inteligência coletiva: por uma antropologia do ciberespaço. São Paulo: Loyola; 1998.

8. Salvador PTCO, Rodrigues CCFM, Ferreira Jr MA, Fernandes MID, Martins JCA, Santos VEP. Construção de hipermídia para apoio ao ensino da sistematização da assistência de enfermagem. Rev. Gaúcha Enferm. 2019;40:e20180035. https://doi.org/10.1590/1983-1447.2019.20180035

9. Alvarez AG, Dal Sasso GTM. Virtual learning objects: contributions to the learning process in health and nursing. Acta Paul Enferm. 2011;24(5):707-11. https://doi.org/10.1590/S0103-21002011000500018 Portuguese.

10. Joanna Briggs Institute. Methodology for JBI Scoping Reviews. Adelaide: The Joanna Briggs Institute; 2015.

11. Tricco AC, Lillie E, Zarin W, O'Brien KK, Colquhoun H, Levac D, et al. PRISMA Extension for Scoping Reviews (PRISMA-ScR): checklist and explanation. Ann Intern Med. 2018;169(7):467-73. https://doi.org/10.7326/M18-0850

12. Costa JB, Peres HHC, Rogenski NMB, Baptista CMC. An educational proposal to teach a pressure ulcer management course online to students and nursing professionals. Acta Paul Enferm. 2009;22(5):607-11. https://doi.org/10.1590/S0103-21002009000500002 Portuguese.

13. Barbosa SFF, Marin HF. Web-based simulation: a tool for teaching critical care nursing. Rev Latino-Am Enferm. 2009;17(1):7-13. https://doi. org/10.1590/S0104-11692009000100002 Portuguese.

14. Yoo JS, Ryue SH, Lee JE, Ahn JA. Evaluation of a Complementary Cyber Education Program for a Pathophysiology Class. Korean J Med Educ. 2009;21(4). https://doi.org/10.3946/kjme.2009.21.4.365

15. Corradi MI, Silva SH, Scalabrin EE. Virtual objects to support the teaching-learning process of physical examination in nursing. Acta Paul Enferm. 2011;24(3):348-53. http://dx.doi.org/10.1590/S0103-21002011000300007 Portuguese.

16. Mehrdad N, Zolfaghari M, Bahrani N, Eybpoosh S. Learning outcomes in two different teaching approach in nursing education in Iran: e-learning versus lecture. Acta Med Iran [Internet]. 2011 [cited 2020 Apr 10];49(5):296-301. Available from: https://pubmed.ncbi.nlm.nih.gov/21713747/.

17. Borhani F, Vatanparast M, Zadeh AA, Ranjbar H, Pour RS. Virtual education effect on cognitive learning and attitude of nursing students towards it. Iran J Nurs Midwifery Res [Internet]. 2011 [cited 2020 Apr 8];16(4):321-4. Available from: https://www.ncbi.nlm.nih.gov/pmc/ articles/PMC3583104/

18. Goyatá SLT, Chaves ECL, Andrade MBT, Pereira RJS, Brito TRP. Teaching the nursing process to undergraduates with the support of computer technology. Acta Paul Enferm. 2012;25(2):243-8. https://doi.org/10.1590/S0103-21002012000200014 Portuguese.

19. Frota NM. Construction and validation of an educational hypermedia about peripheral catheterization [Dissertação] [Internet]. [Fortaleza]: Universidade Federal do Ceará, Fortaleza; 2012[cited 2020 Apr 8]. 130p. Available from: http://www.repositorio.ufc.br/handle/riufc/6992

20. Rocha ATS, Diniz POD, Belian RB, Frazão IS, Cavalcanti AMTS. Mental Health care: a system for teaching in Nursing. J Health Inform [Internet]. 2012 [cited 2020 Apr 8];4:103-7. Available from: http://www.jhi-sbis.saude.ws/ojs-jhi/index.php/jhi-sbis/article/view/238/132 Portuguese.

21. Galvão ECF, Püschel VAA. Multimedia application in mobile platform for teaching the measurement of central venous pressure. Rev Esc Enferm USP. 2012;46(spe):107-15. https://doi.org/10.1590/S0080-62342012000700016

22. Salvador ME, Sakumoto M, Marin HF. Using Moodle in the Discipline of Nursing Informatics. J Health Inform [Internet]. 2013 [cited 2020 Apr 10];5(4):121-6. Available from: http://www.jhi-sbis.saude.ws/ojs-jhi/index.php/jhi-sbis/article/view/268/181 Portuguese.

23. Gagnon MP, Gagnon J, Desmartis M, Njoya M. The impact of blended teaching on knowledge, satisfaction, and self-directed learning in nursing undergraduates: a randomized, controlled trial. Nurs Educ Perspect. 2014;34(6). https://doi.org/10.5480/10-459

24. Montenery SM, Walker M, Sorensen E, Thompson R, Kirklin D, et al. Millennial generation student nurses' perceptions of the impact of multiple technologies on learning. Nurs Educ Perspect. 2013;34(6):405-9. https://doi.org/10.5480/10-451

25. Tamashiro LMC, Peres HHC. Development and assessment of learning objects about intramuscular medication administration. Rev LatinoAm Enferm. 2014;22(6):716-23. https://doi.org/10.1590/0104-1169.3647.2472 Portuguese.

26. Costa CPV, Luz MHBA. Digital learning object for diagnostic reasoning in nursing applied to the integumentary system. Rev Gaúcha Enferm. 2015;36(4):55-62. http://dx.doi.org/10.1590/1983-1447.2015.04.54128 Portuguese.

27. Alavarce DC, Aroldi JBC, Peres HHC, Wharrad H, Santiago MC. Instructional design to develop an online course on urinary catheterization. $J$ Health Inform[Internet]. 2015 [cited 2020 Aug 10]. 7(4):103-9. Available from: http://www.jhi-sbis.saude.ws/ojs-jhi/index.php/jhi-sbis/article/ download/347/247.pdf.

28. Holanda VR, Pinheiro AKB, Holanda ER, Santos MCL. Teaching and Learning in a Virtual Environment: Nursing Students' Attitude. Rev Min Enferm. 2015;19(1):141-7. http://www.dx.doi.org/10.5935/1415-2762.20150012 Portuguese.

29. Granero-Molina J, Fernández-Sola C, López-Domene E, Hernández-Padilla JM, Preto LR, Castro-Sánchez AM. Effects of web-based electrocardiography simulation on strategies and learning styles. Rev Esc Enferm USP. 2015;49(4):650-6. https://doi.org/10.1590/ S0080-623420150000400016

30. Ferreira MVF, Godoy S, Góes FSN, Rossini FP, Andrade D. Lights, camera and action in the implementation of central venous catheter dressing. Rev Latino-Am Enferm. 2015;23(6):1181-6. https://doi.org/10.1590/0104-1169.0711.2664 Portuguese.

31. Avelino CCV, Borges FR, Inagaki CM, Nery MA, Goyatá SLT. Development of a course in the Virtual Learning Environment on the ICNP. Acta Paul Enferm. 2016;29(1):69-76. https://doi.org/10.1590/1982-0194201600010 Portuguese. 
32. Salvador PTCO, Rodrigues CCFM, Lima KYN, Alves KYA, Santos VEP. Use and development of teaching technologies presented in nursing research. Rev Rene. 2015;16(3):442-50. https://doi.org/10.15253/2175-6783.2015000300018 Portuguese.

33. Lee NJ, Chae SM, Kim H, Lee JH, Min HJ, Park DE. Mobile-Based Video Learning Outcomes in Clinical Nursing Skill Education. Comput Inform Nurs. 2016;34(1):8-16. https://doi.org/10.1097/CIN.0000000000000183

34. Avelino CCV, Costa LCS, Buchhorn SMM, Nogueira DA, Goyatá SLT. Teaching-learning evaluation on the ICNP ${ }^{\circledR}$ using virtual learning environment. Rev Bras Enferm. 2017;70(3):602-9. https://doi.org/10.1590/0034-7167-2016-0545 Portuguese.

35. Tobase L, Gianotto-Oliveira R, Peres HHC, Smith N, Polastri TF, Timerman S. The effects of an online basic life support course on undergraduate nursing students' learning. Int J Med Educ. 2017. 8:309-13. https://doi.org/10.5116/ijme.5985.cbce

36. Kim H, Suh EE. The effects of an interactive nursing skills mobile application on nursing students' knowledge, self-efficacy, and skills performance: a randomized controlled trial. Asian Nurs Res. 2018;12(1):17-25. https://doi.org/10.1016/j.anr.2018.01.001

37. Hogan R, Orr F, Fox D, Cummins A; Foureur M. Developing nursing and midwifery students' capacity for coping with bullying and aggression in clinical settings: Students' evaluation of a learning resource. Nurse Educ Pract. 2018;89-94. https://doi.org/10.1016/j.nepr.2017.12.002

38. Padilha JM, Ribeiro ALA, Machado PAP, Ramos J, Costa P. Clinical virtual simulation in nursing education: randomized controlled trial. JMIR Publics. 2018;21(3). https://doi.org/10.2196/11529

39. Galafassi FP, Gluz JC, Galafassi C. Critical Analysis of Recent Researches on Learning Objects and Learning Environments Technologies. Rev Bras Inf Educ. 2013;21(3):41-52. https://doi.org/10.5753/RBIE.2013.21.03.40 Portuguese.

40. Grossi MGR, Lopes AM, Jesus PM, Galvão RRO. A utilização das tecnologias digitais de informação e comunicação nas redes sociais pelos universitários brasileiros. Rev Texto Dig. 2014;10(1):4-23. https://doi.org/10.5007/1807-9288.2014v10n1p4

41. Calil FC, Peres HHC, Zaima J, Tobase L. The scientific production of objects learning in nursing education. J Health Inform [Internet]. 2012 [cited 2020 Apr 16];4(esp):138-43. Available from: http://www.jhi-sbis.saude.ws/ojs-jhi/index.php/jhi-sbis/article/view/245/134

42. Oliveira Jr JK, Silva MAD. As tecnologias de informação e comunicação como ferramenta complementar no ensino da histologia nos cursos odontologia da Região Norte. J Health Inform [Internet]. 2014 [cited 2020 Apr 12];6(2):60-6. Available from: http://www.jhi-sbis.saude.ws/ ojs-jhi/index.php/jhi-sbis/article/view/293/196

43. Parulla CD, Galdino DM, Dal Pai D, Azzolin KO, Cogo ALP. Avaliação de enfermagem: elaboração e desenvolvimento de um curso massivo, aberto e online. Rev Gaúcha Enferm. 2020;41(spe):e20190199. https://doi.org/10.1590/1983-1447.2020.20190199

44. Rocha ATS, Diniz POD, Belian RB, Frazão IS, Cavalcanti AMTS. Cuidado em Saúde Mental: um sistema para ensino em Enfermagem. J Health Inform [Internet]. 2012 [cited 2020 Apr 12];4(esp):103-7. Available from: http://www.jhi-sbis.saude.ws/ojs-jhi/index.php/jhi-sbis/article/ view/238/132

45. Ministério da Educação (BR). Diretrizes Curriculares Nacionais para os cursos de graduação. Brasília: Ministério da Educação; 2001.

46. Trindade CS, Dahmer A, Reppold CT. Objetos de Aprendizagem: Uma Revisão Integrativa na Área da Saúde. J Health Inform [Internet]. 2014 [cited 2020 Apr 14];6(1):20-29. Available from: http://www.jhi-sbis.saude.ws/ojs-jhi/index.php/jhi-sbis/article/view/300/187.

47. Maia MDSA, Silva DG. Práticas pedagógicas em ambientes virtuais de aprendizagem: usos e abusos. EmRede [Internet]. 2020 [cited 2020 Jun 14];7(1):81-95. Availabre from: https://www.aunirede.org.br/revista/index.php/emrede/article/view/555

48. Santos HAS, Carvalho DF, Silva AFG, Rossetto HHP. Blended learning: practical experience in the classroom. Res, Soc Developm. 2020;9(7):e462974332. https://doi.org/10.33448/rsd-v9i7.4332

49. Holanda VR, Pinheiro AKB, Pagliuca LMF. Learning in online education: analysis of concept. Rev Bras Enferm[Internet]. 2013 [cited 2020 Apr 14];66(3):406-11. https://doi.org/10.1590/\$0034-71672013000300016 Portuguese. 